\title{
BANGUNAN BERSEJARAH DI KAWASAN KESAWAN DAN LAPANGAN MERDEKA MENDUKUNG AKTIVITAS PENGEMBANGAN WILAYAH DI KOTA MEDAN
}

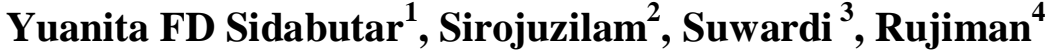 \\ Ilmu Perencanaan Wilayah Sekolah Pascasarjana Universitas Sumatera Utara \\ Jl. Sivitas Akademika No.9, Medan \\ *Email: ${ }^{1}$ hamonitasp@yahoo.co.id, ${ }^{2}$ sirojuzilam@usu.ac.id, ${ }^{3}$ suwardi@usu.ac.id, ${ }^{4}$ rujiman@usu.ac.id
}

\begin{abstract}
ABSTRAK
Medan merupakan salah satu kota di Indonesia yang kaya dengan potensi peninggalan bangunan bersejarah baik warisan kolonial Belanda maupun kerajaan yang berjaya pada masa lalu. Untuk menghindari semakin merosotnya fisik, fungsi dan karakter visual kawasan pusat kota lama ini, diperlukan upaya inovatif yaitu dengan cara menghidupkan kembali suasana lingkungan agar tidak semakin pudar. Kawasan Kesawan dan Lapangan Merdeka dianggap keberadaannya dapat mewakili bangunan bersejarah di Kota Medan, dengan memiliki potensi dari segi arsitektur pada bangunannya dan di kawasan inilah munculnya aktivitas baru dalam menghidupkan kembali suasana lingkungan dan sekitarnya seperti aktivitas bisnis, sarana hiburan dan wisata bagi masyarakat. Penelitian ini dilaksanakan dengan tujuan untuk mengetahui karakteristik Kawasan Kesawan dan Kawasan Lapangan Merdeka dalam pemanfaatan/pelestarian bangunan bersejarah sehingga keberadaannya berpotensi terhadap aktivitas bisnis serta untuk mengkaji sejauhmana faktor tenaga kerja, jumlah jenis dagangan, jumlah pengunjung dan pelayanan pengunjung berpengaruh terhadap pendapatan pedagang di "Kawasan Kesawan dan Merdeka Walk". Metoda analisis yang digunakan adalah regresi linier berganda.Obyek dalam penelitian ini adalah bangunan bersejarah yang dilestarikan berdasarkan Perda No. 6 Tahun 1988, berada di sepanjang Kawasan Kesawan dan bangunan di sekitar Lapangan Merdeka. Sedangkan yang menjadi populasi dalam penelitian ini adalah seluruh masyarakat yang terdiri dari pemilik bangunan, pedagang/pengusaha dan pengunjung yang beraktivitas bisnis di "Kawasan Kesawan dan Merdeka Walk".

Hasil penelitian menunjukkan bahwa (1) pemanfaatan keberadaan bangunan bersejarah di "Kawasan Kesawan" dan "Kawasan Lapangan Merdeka" berfungsi sebagai "Museum Terbuka" untuk masyarakat yang ingin menambah pengetahuannya tentang warisan sejarah di kota Medan dan memiliki nilai jual dari sudut visualisasinya dalam memperkenalkan nilai-nilai sejarah perkembangan arsitektur bangunannya, (2) perkembangan pembangunan yang pesat di "Kawasan Kesawan" dan "Kawasan Lapangan Merdeka" menuntut adanya suatu pelestarian baik preservasi maupun konservasi, sehingga hal ini dapat dijadikan suatu aset komersial bagi kegiatan pariwisata, (3) tenaga kerja, jumlah jenis dagangan, jumlah pengunjung, dan pelayanan pengunjung berpengaruh secara signifikan dalam meningkatkan pendapatan pedagang di "Kawasan Kesawan" dan "Merdeka Walk", (4) Kawasan Kesawan dan Lapangan Merdeka saat ini dapat dijadikan alternatif untuk peningkatan pendapatan asli daerah (PAD) melalui berbagai pungutan, retribusi yang diperoleh karena kawasan ini dijadikan salah satu pusat kuliner di kota Medan.
\end{abstract}

Kata Kunci: Pengembangan Wilayah, Bangunan Bersejarah, Tenaga Kerja, Jumlah Dagangan, Jumlah Pengunjung, Pelayanan Pengunjung.

\section{PENDAHULUAN}

Lokasi kawasan Kesawan adalah awal perkembangan kota Medan modern yang mulai berdiri pada akhir abad XVI dan berkembang pada awal tahun 1800-an. Fungsi yang mendominasi dari kawasan ini adalah gabungan antara fungsi hunian (ruko) 
dan fungsi komersial (perbelanjaan/retail) dan perkantoran. Pada saat ini kawasan Kesawan sedang mengalami perubahan akibat adanya penggunaan fungsi bisnis yang sebagian terpusat di Jalan Ahmad Yani (Kesawan) dan Jalan Balai Kota (Lapangan Merdeka) sehingga di masa akan menjadi daerah yang makin berkembang. Kesawan merupakan kota lama yang memiliki ruang publik terletak di tengah-tengah kota Medan. Dahulunya Kesawan merupakan "kampungnya kota Medan" atau dengan kata lain kampung ini merupakan awal berdirinya kota Medan.

Bangunan yang ada di kawasan Kesawan saat ini terdiri dari bangunan lama bergaya Kolonial dan Tionghoa, gabungan antara bangunan lama dengan yang baru sampai bangunan masa kini. Bangunan lama tersebut sudah mulai berkurang akibat perubahan fungsi bentuk bangunan menjadi ruko oleh pemilik, sehingga kesan sejarah yang ada pada kawasan Kesawan memudar. Apalagi saat ini papan reklame yang banyak menutupi fasade bangunan. Pada saat ini, ruang terbuka publik pada Kawasan Kesawan lebih diperioritaskan pada kegiatan komersial yaitu rekreasi dan hiburan. Kesawan dilestarikan karena kawasan ini meninggalkan bangunan-bangunan lama yang cukup antik dan menarik agar tetap dapat dipertahankan, sehingga dapat menarik perhatian pengunjung baik dari turis mancanegara, turis lokal dan masyarakat kota Medan. Kawasan di sekitar Lapangan Merdeka didominasi oleh kegiatan perkantoran dan jasa, sedangkan pada Lapangan Merdeka sendiri kegiatan yang ada berupa rekreasi, olah raga dan sebagai transit bagi para pengunjung selama 24 jam. Bangunan yang berdiri sekitar Lapangan Merdeka juga terdiri dari bangunan bersejarah. Lapangan Merdeka juga merupakan lapangan yang memiliki nilai bersejarah dimana setiap ada moment kebesaran memperingati Hari Kemerdekaan Republik Indonesia, memperingati hari jadi Kota Medan dan lain sebagainya menggunakan lapangan ini. Untuk menikmati suasana sekitar Lapangan sMerdeka maka dibangun "Merdeka Walk" oleh pihak swasta yang difasilitasi Pemerintah Kota di atas lahan seluas $6.600 \mathrm{~m}^{2}$ pada tahun 2005 . Kegiatan wisata kulinerpun ikut memarakkan suasana sepanjang ruang publik seperti di Lapangan Merdeka Medan. Ruang terbuka publik merupakan bagian dari pembangunan wilayah di perkotaan yang sangat penting untuk diperhatikan.

Koridor "Kawasan Kesawan" (Jalan Ahmad Yani) dan "Merdeka Walk" (Lapangan Merdeka) merupakan wilayah yang memiliki nilai historis yang tinggi, baik dari bangunan maupun lingkungannya sendiri. Perkembangan pembangunan yang pesat menuntut adanya suatu pelestarian baik preservasi maupun konservasi, sehingga hal ini dapat dijadikan suatu aset komersial bagi kegiatan wisata.

Berdasarkan latar belakang di atas, maka dapat dirumuskan permasalahan sebagai berikut:

1. Bagaimana profil/kondisi karakteristik Kawasan Kesawan dan Kawasan Lapangan Merdeka, dalam pemanfaatan/pelestarian bangunan bersejarah sehingga keberadaannya berpotensi terhadap munculnya aktivitas bisnis di "Kawasan Kesawan" dan "Merdeka Walk"?

2. Apakah faktor tenaga kerja, jumlah jenis dagangan, jumlah pengunjung dan pelayanan pengunjung berpengaruh terhadap pendapatan pedagang di "Kawasan Kesawan" dan "Merdeka Walk"?

Berdasarkan rumusan masalah di atas, maka tujuan penelitian ini adalah:

1. Untuk mengetahui profil/kondisi karakteristik kawasan Kesawan dan Lapangan Merdeka, dalam pemanfaatan/pelestarian bangunan bersejarah sehingga keberadaannya berpotensi terhadap munculnya aktivitas bisnis di "Kawasan Kesawan" dan "Merdeka Walk".

2. Menjelaskan faktor tenaga kerja, jumlah jenis dagangan, jumlah pengunjung dan pelayanan pengunjung, berpengaruh terhadap pendapatan pedagang di

"Kawasan Kesawan" dan "Merdeka Walk".

\section{METODE PENELITIAN}

\section{Lokasi Penelitian}

Jalan Ahmad Yani yaitu Kesawan dan di Jalan Balai Kota yaitu Lapangan Merdeka Medan. 


\section{Populasi dan Sampel Penelitian}

Populasi dalam penelitian ini adalah seluruh masyarakat yang terdiri dari pemilik bangunan, pedagang/pengusaha dan pengunjung yang beraktivitas bisnis di "Kawasan Kesawan" maupun yang beraktivitas bisnis di "Merdeka Walk".

Sampel dalam penelitian ini ditetapkan dengan teknik cluster sampling. Cluster Sampling adalah cara pengambilan sample terhadap satu atau beberapa kelompok secara acak (Sudjana, 1986). Teknik cluster sampling digunakan untuk menentukan sampel bila objek yang akan diteliti atau data sangat luas, misalnya dari suatu negara, propinsi, kabupaten atau kecamatan. Untuk menentukan masyarakat mana yang dijadikan sumber data, maka pengambilan sampel didasarkan pada daerah/kawasan dari populasi yang ditetapkan. Teknik sampel daerah dilakukan melalui dua tahap. Pertama, menentukan sampel kawasan. Kawasan yang akan menjadi cluster sampling pada penelitian ini adalah kesawan dan lapangan merdeka dengan daerah aktivitas bisnis sepanjang Kawasan Kesawan dan Merdeka Walk. Kedua, adalah menentukan masyarakat/orang yang ada pada kawasan tersebut.

Penetapan anggota sampel berjumlah 80 orang, alasan penetapan sampel tersebut mengikuti pendapat Roscoe (dalam Sugiyono,2003), yang mengatakan:

1. Ukuran sampel yang layak digunakan dalam penelitian sosial adalah antara 30 sampai dengan 500.

2. Bila dalam penelitian akan melakukan analisis dengan multivariate (korelasi atau regresi berganda), maka jumlah anggota sampel minimal 10 kali dari jumlah variabel yang diteliti (independent ditambah dependen).

Berdasarkan pendapat di atas, peneliti menetapkan sampel penelitian sebanyak 80 orang yang terdiri dari 40 orang berada di "Kawasan Kawasan Kesawan" dan 40 orang lagi berada di "Kawasan Merdeka Walk", dengan alasan:

1. Telah melebihi ambang batas kriteria Roscoe, yakni batasan minimal 30 orang, dan telah melebihi 10 kali dari 4 (empat) variabel yang akan diteliti.
2. Masyarakat yang hendak diteliti adalah terdiri dari pemilik bangunan, pedagang/pengusaha dan pengunjung yang beraktivitas bisnis di "Kawasan Kesawan" maupun yang beraktivitas bisnis di "Merdeka Walk". Responden pemilik bangunan akan disebarkan keseluruh masyarakat yang tinggal/menghuni di bangunan di sepanjang Kawasan Kesawan dan Kawasan Lapangan Merdeka untuk mengetahui fungsi bangunan, kondisi bangunan konservasi dan bangunan baru/bukan konservasi serta status kepemilikannya. Data responden tersebut mendukung analisa deskriptif. Sedangkan responden pedagang/pengusaha dan pengunjung masing-masing kelompok responden tersebut diambil sampel 40 orang di setiap kawasan. Dengan demikian penetapan anggota sampel sebanyak 80 orang dianggap telah representatif.

\section{Metode Pengumpulan Data}

Data yang diperlukan dalam penelitian ini terdiri dari data primer dan data sekunder baik yang bersifat kualitatif maupun kuantitatif.

Data yang dikumpulkan berupa data primer yang diperoleh dengan cara wawancara langsung kepada responden (pemilik bangunan bersejarah, pengusaha/pedagang dan pengunjung yang berada di Kawasan Kesawan dan Merdeka Walk) dengan pengisian daftar pertanyaan yang dirancang khusus untuk penelitian ini. Data sekunder yang diperoleh dari kantor BPS (Badan Pusat Statistik) kota Medan, Pemko Medan, BWS (Badan Warisan Sumatera), literatur dan hasil penelitian sebelumnya yang berkaitan dengan penelitian ini.

\section{Metode Analisis}

Untuk permasalahan pertama, dianalisis secara analisis deskriptif yaitu gambaran keseluruhan meliputi perkembangan arsitektur Kolonial, identitas bangunan bersejarah, fungsi bangunan, kondisi bangunan konservasi dan bangunan baru/bukan konservasi (dilengkapi peta dan gambar) serta 
status kepemilikannya sebagai potensi pelestarian bangunan bersejarah.

Sedangkan untuk menguji hipotesis kedua dianalisis dengan statistik regresi linier berganda dengan rumus:

$\log Y=\log a+b 1 \log . x 1+b 2 \log . x 2+b 3$ $\log . x 3+b 4 \log . x 4+\mu$

Keterangan:

$\mathrm{Y}=$ Pendapatan responden (dalam rupiah perbulan)

$\mathrm{X} 1=$ Tenaga Kerja (dalam satuan orang)

$\mathrm{X} 2=$ Jenis Dagangan (dalam satuan unit/item perjenis barang dagangan)

$\mathrm{X} 3=$ Jumlah Pengunjung (dalam satuan orang perhari)

$\mathrm{X} 4=$ Pelayanan Pengunjung (dummy variabel)

$\begin{array}{lll}\mathrm{A} & = & \text { Konstanta } \\ \mu & = & \text { Error Term }\end{array}$

\section{HASIL PENELITIAN}

\section{Identifikasi}

\section{Lama/Bersejarah di Kawasan} Kesawan dan Lapangan Merdeka

Dalam perkembangan arsitektur dari segi masa, perubahan bentuk dapat dibedakan dalam dua hal (Yulianto Sumalyo, 1988:2) sebagai berikut:

1. Perubahan secara pelan-pelan atau evolusioner. Yang digolongkan ke dalam kategori pertama adalah arsitektur klasik dan tradisional, berkembang mengalami perubahan dalam waktu berpuluh-puluh tahun bahkan beratus-ratus tahun.

2. Perubahan secara cepat. Yang digolongkan ke dalam kategori kedua ini adalah arsitektur modern, berkembang dan berubah cepat, sejalan dengan cepatnya perkembangan teknologi dan penduduk.

Dengan keterangan perkembangan arsitektur dari segi masa, maka perubahan bentuk arsitektur kolonial di Indonesia termasuk kategori kedua. Bentuk arsitektur kolonial Belanda di Indonesia sesudah tahun 1900-an merupakan suatu bentuk yang spesifik. Bentuk tersebut merupakan hasil kompromi dari arsitektur modren yang berkembang di Belanda, dan pada zaman yang bersamaan pula dengan iklim tropis basah (arsitektur tropis) di Indonesia. Ada juga beberapa bangunan arsitektur kolonial Belanda yang mengambil elemen-elemen tradisional setempat yang kemudian diterapkan ke dalam bentuk arsitekturnya. Hasil keseluruhan dari arsitektur kolonial Belanda di Indonesia tersebut adalah suatu bentuk khas yang berlainan dengan arsitektur modren yang ada di Belanda sendiri. Maka dari itu jika ditinjau dari perkembangan arsitektur di kawasan Kesawan dan Lapangan Merdeka yang merupakan sebagai bagian dari Hindia Belanda pada waktu itu, tentu saja tidak bisa lepas dari perkembangan arsitektur Hindia Belanda secara keseluruhan dan yang uniknya terdapat pada detail-detail bangunan seperti pada bukaan jendela, ventilasi, talang air, pintu, ornamen-ornamen dan lain sebagainya. Sebagian arsitektur kolonial Belanda yang terdapat di Kawasan Kesawan mengambil elemen-elemen tradisional China. Ini menggambarkan bahwa pada masa itu pengaruh masuknya Tjong A Fie ke Medan, menuntun saudagar-saudagar yang etnis China lainnya bermukim sambil berdagang di sepanjang Kawasan Kesawan yang kemudian menjadi pusat bisnis di Medan. Kecermatan Tjong A Fie melihat peluang bisnis tahun 1886 maka memindahkan pusat imperium bisnisnya di Kesawan. Tjong A Fie membangun megah rumahnya di Kesawan yang berdiri sejak akhir tahun 1800-an dengan arsitektur bergaya Tiongkok kuno. Beberapa bentuk dan ornamen arsitektur Tiongkok inilah diadopsi dan diterapkan pada sebagian fasade bangunan rumah toko maupun rumah tinggal yang ada di sepanjang Kesawan. Di Indonesia, kebiasaan membuat tower yang ujungnya diberi atap rupanya menjadi mode pada arsitektur kolonial Belanda pada awal abad ke 20 .

\section{Data Kondisi Bangunan Kesawan dan Lapangan Merdeka}

\section{Data Kondisi Bangunan Disekitar Jalan}

Ahmad Yani (Kesawan Medan)

1. Jalan Ahmad Yani Sebelah Kanan

(View dari Jalan Pemuda)

Ditinjau dari segi fungsi bangunan maka kondisi bangunan yang berada di Jalan Ahmad Yani sebelah kanan (view dari Jalan Pemuda) memiliki persentase sebagai berikut menunjukkan bahwa bangunan berfungsikan aktivitas bisnis sebesar 52\%, 
berfungsikan hunian $23 \%$, berfungsikan kantor $6 \%$, berfungsikan gudang sebesar $3 \%$ dan bangunan yang masih berdiri utuh tetapi tidak difungsikan sama sekali/kosong sebesar $11 \%$. Ditinjau dari bangunan konservasi, maka yang termasuk didalam pembahasan ini adalah bangunan konservasi bagian fasade saja, secara keseluruhan (lantai, warna, material atap, tangga dan lain sebagainya), tambah lantai dan bangunan baru/bukan konservasi (menjelaskan seberapa besar jumlah bangunan lama di Kesawan yang sudah dirobah menjadi bangunan baru). Menunjukkan bahwa bangunan lama yang mengalami konsevasi sebesar $80 \%$ yang terdiri dari $8 \%$ fasade saja, $12 \%$ tambah lantai dan $60 \%$ keseluruhan. Sedangkan bangunan lama yang dirobah total menjadi bangunan baru terdapat 5\%, dan 15\% bangunan tidak terawat karena mengingat kondisi bangunan yang kosong. Ditinjau dari status kepemilikan bangunan maka yang terangkum pada pembahasan ini adalah bangunan tersebut milik sendiri, warisan ataupun sewa/kontrak. Maka berdasarkan status kepemilikan bangunan maka sebesar $73 \%$ mengatakan milik sendiri, 3\% mengatakan warisan keluarga, $8 \%$ mengatakan disewa/kontrak sedangkan $16 \%$ tidak diketahui mengingat kondisi bangunan kosong dan tidak dihuni.

2. Jalan Ahmad Yani Sebelah Kiri

(View dari Jalan Pemuda)

Ditinjau dari segi fungsi bangunan maka kondisi bangunan yang berada di jalan Ahmad Yani sebelah kiri (view dari jalan Pemuda) memiliki persentase sebagai berikut: menjelaskan bahwa fungsi bangunan yang dipergunakan untuk beraktivitas bisnis sebesar $46 \%$, bangunan berfungsi sebagai hunian sebesar $23 \%$, bangunan berfungsi sebagai kantor sebesar $18 \%$ dan 3\% bangunan melakukan tahap rehabilitasi sebagai bagian dari konsep pelestarian bangunan bersejarah/lama. Sedangkan $10 \%$ bangunan tidak berfungsi mengingat kondisi bangunan kosong tetapi kondisi exterior bangunan tetap di beri sentuhan warna dan perawatan.

Ditinjau dari bangunan konservasi, maka yang termasuk didalam pembahasan ini adalah bangunan konservasi bagian fasade saja, secara keseluruhan (lantai, warna, material atap, tangga dan lain sebagainya), tambah lantai dan bangunan baru/bukan konservasi (menjelaskan seberapa besar jumlah bangunan lama di Kesawan yang sudah dirobah menjadi bangunan baru). Menunjukkan bahwa bangunan lama yang mengalami konsevasi sebesar $78 \%$ yang terdiri dari $4 \%$ fasade saja, $10 \%$ tambah lantai dan $64 \%$ keseluruhan. Sedangkan bangunan lama yang dirobah total menjadi bangunan baru terdapat 22\%. Ditinjau dari status kepemilikan bangunan maka yang terangkum pada pembahasan ini adalah bangunan tersebut milik sendiri, warisan ataupun sewa/kontrak. Maka berdasarkan status kepemilikan bangunan maka sebesar $70 \%$ mengatakan milik sendiri, $1 \%$ mengatakan warisan keluarga, $17 \%$ mengatakan disewa/kontrak sedangkan $12 \%$ tidak diketahui mengingat kondisi bangunan kosong dan tidak dihuni.

\section{Data Kondisi Bangunan Disekitar Kawasan}

\section{Lapangan Merdeka Medan}

Ditinjau dari segi fungsi bangunan maka kondisi bangunan yang berada di Kawasan Lapangan Merdeka memiliki persentase sebagai berikut menunjukkan bahwa bangunan berfungsikan aktivitas bisnis sebesar 83\%, berfungsikan kantor 14\%, berfungsikan Stasiun Kereta Api sebagai jasa transportasi sebesar 1\%, berfungsikan Tempat Ibadah sebesar 1\% dan bangunan yang masih berdiri utuh tetapi tidak difungsikan sama sekali/kosong sebesar $1 \%$.

Ditinjau dari bangunan konservasi, maka yang termasuk didalam pembahasan ini adalah bangunan konservasi bagian fasade saja, secara keseluruhan (lantai, warna, material atap, tangga dan lain sebagainya), tambah lantai dan bangunan baru/bukan konservasi (menjelaskan seberapa besar jumlah bangunan lama di Kesawan yang sudah dirobah menjadi bangunan baru).menunjukkan bahwa bangunan lama yang mengalami konsevasi secara keseluruhan sebesar 30\%. Sedangkan bangunan lama yang dirobah total menjadi bangunan baru terdapat $70 \%$. Ini membuktikan bangunan bersejarah/lama di Kawasan Lapangan Merdeka dalam keadaan sangat memprihatinkan. Oleh karena itu tidak ada kata terlambat untuk 
melestarikan keadaan bangunan bersejarah/lama yang masih tinggal $30 \%$ tersebut

Ditinjau dari status kepemilikan bangunan maka yang terangkum pada pembahasan ini adalah bangunan tersebut milik sendiri, warisan ataupun sewa/kontrak. Terlihat bahwa berdasarkan status kepemilikan bangunan maka sebesar $69 \%$ mengatakan milik sendiri dan $31 \%$ mengatakan disewa/kontrak.

\section{Identitas Responden}

\section{Umur Responden}

Berdasarkan umur responden yang diteliti maka umur yang terendah adalah 17 tahun dan yang tertinggi mencapai 53 tahun. Umur responden yang berkisar $1(1,25 \%)$ kurang dari 17 tahun, $36(45 \%)$ responden berumur 18-27 tahun, $23(28,75 \%)$ responden berumur $28-37$ tahun, $17(21,25 \%)$ responden berumur $38-47$ tahun, dan $3(3,75 \%)$ responden berumur $48-58$ tahun.

\section{Pendidikan Responden}

Jenjang pendidikan responden terdiri dari lima tingkatan, tamat SD, tamat SLTP, tamat SLTA, tamat dari akademi (baik pada jenjang diploma tiga maupun diploma satu dan tamat dari perguruan tinggi ( baik pada jenjang strata dua maupun strata satu). Dari 80 responden yang diteliti, sebanyak $3(3,75 \%)$ responden berpendidikan SD, 4 (5\%) responden berpendidikan SLTP, 49 $(61,25 \%)$ responden berpendidikan SLTA, 7 $(8,75 \%)$ berpendidikan diploma dan 17 $(21,25 \%)$ berpendidikan Sarjana.

\section{Pekerjaan Responden}

Pekerjaan responden pada umumnya adalah pengusaha (6 orang dari responden pengunjung dan 40 orang dari responden pengusaha di Kawasan Kesawan dan Merdeka Walk) dengan perincian sebagai berikut : dari 80 responden dalam penelitian ini sebanyak 46 $(57,7 \%)$ adalah pengusaha, $13(16,25 \%)$ pekerjaan sebagai karyawan swasta, $12(15 \%)$ pekerjaan adalah sebagai pedagang, $4(5 \%)$ pekerjaannya sebagai dosen, 3 (3,75\%) pekerjaan sebagai pegawai negri sipil, $1(1,25 \%)$ pekerjaan sebagai guru private dan $1(1,25 \%)$ masih sebagai mahasiswa.

\section{Faktor-faktor yang Berpengaruh Terhadap Pendapatan Pedagang di "Kawasan Kesawan" dan "Merdeka Walk"}

\section{$\underline{\text { Jumlah Tenaga Kerja }}$}

Yang dimaksud dengan jumlah tenaga kerja adalah jumlah total keseluruhan orang yang bekerja di gerai makanan. Dan jumlah responden merupakan para pengusaha gerai makanan/pemilik yang menggaji/upah tenaga kerja tersebut.

Mengenai tenaga kerja yang digunakan responden, terdiri dari satu hingga tujuh belas orang. Responden yang menggunakan tenaga kerja satu orang, delapan orang dan tujuh belas orang, masing-masing terdapat 5 persen. Responden yang menggunakan tenaga kerja dua orang dan enam orang sama-sama terdapat 10 persen. Yang menggunakan tenaga kerja tiga orang terdapat 25 persen , menggunakan tenaga kerja empat orang terdapat 7,5 persen sedangkan menggunakan tenaga kerja lima orang terdapat 22,5 persen. Selebihnya yang menggunakan tenaga kerja tujuh orang, dua belas orang, tiga belas orang dan empat belas dengan masingmasing terdapat 2,5 persen.

\section{Jumlah Jenis Dagangan}

Jenis dagangan yang disajikan responden sangat bervariasi, seperti makanan berupa hidangan porsi berat: nasi, ikan panggang, ayam goreng, pizza dan lain-lainnya. Hidangan porsi ringan: kentang goreng, dim sum, sate vegatarian dan lain-lainnya, serta juga makanan ringan: roti, kue dan krupuk. Selain makanan responden juga menyajikan minuman yang variasi dalam rasanya. Dari jumlah jenis dagangan yang didagangkan responden, minimal berjumlah sepuluh macam (item) dan maksimal berjumlah empat puluh lima macam. Responden yang memiliki jumlah jenis dagangan antara 10 hingga 15 macam berjumlah 35 persen. Responden yang menjual dagangan antara 16 hingga 20 macam berjumlah 27,5 persen. Sedangkan responden yang memiliki jenis dagangan antara 21 hingga 25 macam dan 31 hingga 35 macam masing-masing sama 10 persen. Responden yang memiliki 26 hingga 30 jenis dagangan serta yang memiliki 36 hingga 40 macam masing-masing berjumlah 7,5 persen. Dan responden yang memiliki jenis dagangan yang terbanyak 41 hingga 45 macam berjumlah 2,5 persen. 


\section{Jumlah Pengunjung}

Jumlah pengunjung yang datang setiap hari untuk makan di gerai makanan responden paling sedikit terdapat sepuluh pengunjung dan pengunjung yang setiap hari paling banyak adalah lima puluh pengunjung.

Responden yang menjawab banyaknya pengunjung yang datang untuk datang dan makan di gerai responden antara 10 hingga 20 orang perhari terdapat 62,5 persen. Yang menjawab 21 hingga 30 orang perhari terdapt 17,5 persen sementara responden yang mengatakan 41 hingga 50 orang perhari terdapat 12,5 persen. Dan responden yang mengatakan banyaknya pengunjung yang datang antara 31 hingga 40 orang perhari

\section{Pelayanan Pengunjung}

Pelayanan yang diberikan oleh pihak pedagang "Kawasan Kesawan" dan "Merdeka Walk" kepada pengunjung juga dapat mempengaruhi minat pengunjung datang kembali lagi untuk berkreasi bersama keluarga dan menikmati wisata kuliner serta suasana sekitarnya. Menurut pengunjung pelayanan yang diberikan oleh pihak pedagang "Kawasan Kesawan" dan "Merdeka Walk" umumnya baik (ramah/komunikatif)

Berdasarkan penjelasan di atas, pelayanan yang diberikan pihak pedagang "Kawasan Kesawan" dan "Merdeka Walk" kepada responden/pengunjung dengan tanggapan responden yang menjawab baik (ramah/komunikatif) sebanyak 52,5 persen dan responden/pengunjung yang menjawab pelayanan yang tidak baik (tidak ramah/tidak komunikatif) sebanyak 47,5 persen. Dengan demikian pelayan yang baik (ramah/komunikatif) dapat mempengaruhi minat pengunjung datang kembali lagi untuk berkreasi bersama keluarga dan menikmati wisata kuliner serta suasana sekitar "Kawasan Kesawan" dan "Merdeka Walk".

\section{Pengujian Hipotesa}

Setelah menguraikan faktor-faktor yang berpengaruh terhadap pendapatan pedagang di "Kawasan Kesawan" dan "Merdeka Walk", maka selanjutnya dilakukan pengujian hipotesis yang mengatakan "faktor-faktor jumlah tenaga kerja, jumlah jenis dagangan, jumlah pengunjung dan pelayanan pengunjung berpengaruh signifikan terhadap pendapatan pedagang di "Kawasan Kesawan" dan "Merdeka Walk".

Berdasarkan hasil uji statistik dengan menggunakan analisis regresi berganda, menunjukkan bahwa koefisien determinasi (Adjusted $\mathrm{R}^{2}$ ) untuk model ini meyakinkan yakni sebesar 0,853 (hasil setelah di log). Artinya, terdapat 85,3 persen faktor pendapatan mampu dijelaskan oleh variasi himpunan variabel independen (yaitu tenaga kerja, jenis dagangan, jumlah pengunjung dan pelayanan pengunjung). Sedangkan sisanya (100\% - 85,3\% $=14,7 \%$ ) dipengaruhi oleh variabel-variabel lain yang tidak dimasukkan dalam model estimasi penilaian ini.

Tabel 1 memperlihatkan bahwa nilai $\mathrm{F}$ hitung signifikan pada tingkat kepercayaan 95 persen, dan t-hitung untuk variabel tenaga kerja, jenis dagangan, jumlah pengunjung dan pelayanan pengunjung juga berpengaruh signifikan. Hal ini memberikan gambaran bahwa model yang digunakan dalam analisis ini cukup baik untuk mengestimasi parameter variabel yang diikutsertakan dalam model. Untuk melihat signifikan koefisien regresi terhadap setiap variabel bebas dilakukan uji t. Dengan ketentuan: $\mathrm{Ho}=0 ; \mathrm{H} 1 \neq 0$, jika thitung < t- Tabel maka Ho diterima, sebaliknya jika t-hitung $>$ t-Tabel maka Ho ditolak. 
Tabel 1. Rangkuman Hasil Analisis Regresi Berganda Antara Tenaga Kerja, Jenis Dagangan, Jumlah Pengunjung dan Pelayanan Pengunjung Dengan Pendapatan Pedagang

\begin{tabular}{|c|c|c|c|c|}
\hline Variabel & Koef. Regresi & Stand. Error & t-hitung & Signifikan \\
\hline Intercept & 6,060 & 0,083 & & \\
\hline $\begin{array}{r}\text { Tenaga Kerja } \\
\text { (X1) }\end{array}$ & 0,516 & 0,052 & 9,923 & 0,000 \\
\hline $\begin{array}{l}\text { Jenis Dagangan } \\
\text { (X2) }\end{array}$ & 0,123 & 0,048 & 2,562 & 0,015 \\
\hline $\begin{array}{l}\text { Jumlah Pengunjung } \\
\text { (X3) }\end{array}$ & 0,338 & 0,052 & 6,540 & 0,000 \\
\hline $\begin{array}{c}\text { Pelayanan } \\
\text { Pengunjung } \\
(\mathrm{X} 4)\end{array}$ & 0,053 & 0,019 & 2,836 & 0,008 \\
\hline$=40$ & & & & \\
\hline$=0,853$ & & & & \\
\hline$=50,906$ & & & & \\
\hline
\end{tabular}

Secara parsial, pengaruh dari variabel tenaga kerja, jenis dagangan, jumlah pengunjung dan pelayanan pengunjung dapat diinterpretasikan sebagai berkut:

\section{Tenaga Kerja}

Hasil penelitian menunjukkan bahwa variabel tenaga kerja berpengaruh positif dan signifikan pada derajat satu persen dengan koefisien sebesar 0,516. Hal ini memberikan pengertian bahwa penambahan satu orang tenaga kerja akan menaikkan pendapatan sebesar $0,516 \%$. Dengan taraf signifikan pada derajat kepercayaan 5\%, maka variabel tenaga kerja menunjukkan signifikansi t-hitung $(9,923)$ lebih besar daripada t-Tabel $(1,994)$.

2. Jumlah Jenis Dagangan

Hasil penelitian menunjukkan bahwa variabel jumlah jenis dagangan berpengaruh positif dan signifikan pada derajat satu persen dengan koefisien sebesar 0,123. Hal ini memberikan pengertian bahwa penambahan satu jenis dagangan akan menaikkan pendapatan sebesar 0,123 persen. Dengan taraf signifikan pada derajat kepercayaan 5 persen, maka variabel jumlah jenis dagangan menunjukkan signifikansi t-hitung $(2,562)$ lebih besar daripada t-Tabel $(1,994)$.

3. Jumlah Pengunjung

Hasil penelitian menunjukkan bahwa variabel jumlah pengunjung berpengaruh positif dan signifikan pada derajat satu persen dengan koefisien sebesar 0,338 . Hal ini memberikan pengertian bahwa penambahan satu orang jumlah pengunjung akan menaikkan pendapatan sebesar
0,338\%. Dengan taraf signifikan pada derajat kepercayaan 5\%, maka variabel jumlah pengunjung menunjukkan signifikansi

t-hitung $(6,540)$ lebih besar daripada tTabel $(1,994)$.

4. Pelayanan Pengunjung

Untuk variabel pelayanan pengunjung digunakan variabel dummy. Hasil penelitian menunjukkan bahwa variabel pelayanan pengunjung berpengaruh secara positif dan signifikan pada derajat satu persen dengan koefisien sebesar 0,053. Hal ini memberikan pengertian bahwa ada perbedaan yang nyata antara pendapatan pengusaha dengan cara memberikan pelayanan yang baik dengan yang tidak baik. Dengan taraf signifikan pada derajat kepercayaan 5 persen, maka variabel pelayanan pengunjung menunjukkan signifikansi t-hitung $(2,836)$ lebih besar daripada t-Tabel $(1,994)$.

Angka F hitung sebesar 50,906 pada taraf signifikan pada derajat kepercayaan 5 persen, karena probabilitasnya menunjukkan angka 0,000 yang jauh lebih kecil dari pada 0,05 , maka model regresi ini dapat dipakai untuk memprediksikan pendapatan pedagang di "Kawasan Kesawan" dan "Merdeka Walk". Dengan kata lain bahwa tenaga kerja, jumlah jenis dagangan, jumlah pengunjung dan pelayanan pengunjung secara bersama-sama berpengaruh secara signifikan terhadap pendapatan pedagang.

Dengan melakukan perbandingan antara $\mathrm{F}$ hitung dengan $F$ Tabel juga menunjukkan bahwa keempat variabel bebas berpengaruh signifikan terhadap variabel terikat. F hitung 
sebesar 50,906; sedangkan $\mathrm{F}$ Tabel adalah sebesar 2,80 dengan tingkat signifikansi pada derajat kepercayaan 5 persen, karena $\mathrm{F}$ hitung lebih besar dari pada F Tabel, maka Ho ditolak, berarti terdapat pengaruh yang signifikan antara tenaga kerja, jumlah jenis dagangan, jumlah pengunjung dan pelayanan pengunjung dengan pendapatan pedagang di "Kawasan Kesawan" dan "Merdeka Walk".

Dengan demikian baik diuji secara serentak maupun secara parsial, keempat variabel bebas (tenaga kerja, jenis dagangan, jumlah pengunjung dan pelayanan pengunjung) berpengaruh secara positif dan signifikan mempengaruhi terhadap pendapatan pedagang di "Kawasan Kesawan" dan "Merdeka Walk".

\section{KESIMPULAN}

Berdasarkan hasil penelitian yang dilakukan maka dapat diambil beberapa kesimpulan antara lain:

1. Kurang maksimal dan ketidak tegasan dari pemerintah dalam merumuskan Perda No.6 Tahun 1988 tentang pelestarian bangunan bersejarah, yang dibuktikannya masih ada pemberian ijin untuk merubah ataupun merombak total bangunan bersejarah/lama menjadi bangunan baru. Begitu juga sikap dari pemilik bangunan bersejarah di Kawasan Kesawan khususnya kurang pedulinya dan kurang tanggapnya dalam merawat maupun menata kembali wajah bangunan agar lebih baik dan indah secara visulisasi. Serta membiarkan bangunan kosong dan tidak berfungsi sama sekali, padahal justru itu yang makin membuat kekumuhan dari bangunan lama semakin tidak layak dihuni. Di sisi lain terdapat kecenderungan rendahnya kepedulian Dinas Pariwisata baik tingkat Sumatera Utara maupun Kota Medan dalam mengatasi krisis pengetahuan masyarakat tentang nilai-nilai sejarah di Kawasan Kesawan dan Lapangan Merdeka. Nilai-nilai sejarah itu antara lain meliputi bangunan dan perkembangan kota yang pada sekitar tahun 1888 telah menjadi sentra bisnis kota Medan. Cikal bakal sentra bisnis kota Medan itu diikuti penyediaan fasilitas kota dalam bentuk open space (ruang terbuka publik) yang sekarang ini dikenal sebagai Lapangan Merdeka serta jalur kereta api pada tahun 1934 yang sekarang dikenal sebagai Stasiun kereta api Medan. Mengenai biaya yang dikeluarkan konsumen juga besar membuat konsumen yang datang terbatas dari kalangan menengah keatas saja. Padahal seharusnya semua kalangan masyarakat Kota Medan harus bisa menikmati fasilitas kota yaitu open space (ruang terbuka publik). Akan lebih baik jikalau konsep yang dijual lebih merakyat, desain outdoor lebih ke natural/alam sehingga view ke bangunan sekitarnya lebih jelas didukung konsep desain funiture bergaya tempo dulu , makanan yang disajikan mencirikhaskan Kota Medan, retail-retail menyediakan hasil-hasil dari Usaha Kecil Menengah (UKM) serta pengrajin Indonesia serta biaya yang ditawarkan terjangkau sehingga dapat dinikmati oleh kalangan bawah menengah sampai kalangan atas. Jikalau ini ditampilkan akan bersifat abadi dan lebih banyak menarik datangnya wisatawan manca negara, nusantara dan lokal.

2. Pada kenyataannya kondisi yang terlihat kurang peduli dalam berpartisipasi kegiatan pelestarian, tetapi jikalau ditinjau dari aktivitas bisnis di "Kawasan Kesawan" dan "Merdeka Walk" yang diuji secara parsial maupun serempak, keempat variabel bebas, yaitu: variabel tenaga kerja (X1), variabel jumlah jenis dagangan (X2), variabel jumlah pengunjung (X3), dan variabel pelayanan pengunjung (X4) berpengaruh secara signifikan dalam meningkatkan pendapatan pedagang di "Kawasan Kesawan" dan "Merdeka Walk" dengan taraf kepercayaan $95 \%$.

Oleh karena itu, konsep pelestarian karakteristik kawasan Kesawan dan Lapangan Merdeka dengan aktivitas bisnis di "Kawasan Kesawan" dan "Merdeka Walk" kiranya seimbang dan saling berpengaruh positif sehingga aset nasional dalam bentuk bangunan bersejarah penting dirawat bahkan dapat dijadikan salah satu unggulan sektor pariwisata di Sunatera Utara, terutama di kota Medan. 


\section{Daftar Pustaka}

Aldwin Surya (2006) Perubahan Sosial Masyarakat Kota Metropolitan, Medan: Kopertis Wilayah I NAD-Sumut.

Adisti Maritadinda Adamar. 2005. Perancangan Ruang Terbuka Publik Lama Kesawan, Medan. Jakarta: Tugas Akhir Universitas Trisakti.

Badan Pusat Statistik Kota Medan. 2006. Kecamatan Medan Barat Dalam Angka, Medan.

Bachtiar Hassan Miraza. 2005. Perencanaan dan Pengembangan Wilayah. Bandung: ISEI Bandung.

Datter, Richard, FAIA. 1995. Civil Architecture, The New Public Infrastructure.

Departemen Pendidikan dan Kebudayaan. 1993. Kamus Besar Bahasa Indonesia, Jakarta: Balai Pustaka.

Eko Budihardjo. 1992. Arsitektur dan Kota di Indonesia, Bandung: Alumni.

Gothfried, Herbert dan Jan Jenning. 1988. American Vernaculer Design 18701940, Iowa State University Press.

Hasti Tarekat. 2002. "Efektifitas Peraturan Daerah No. 6 Tahun 1988 Tentang Perlindungan Bangunan Bersejarah Dalam Upaya Pelestarian Bangunan Bersejarah Di Kota Medan”. Medan: Tesis Magister PWK-USU.

Handinoto. 1996. Perkembangan Kota dan Arsitektur Kolonial Belanda di Surabaya 1870-1940, Yogyakarta. Andi Offset.

Ismail Seraggeldin. 1999. Very Spesial Places: The Architecture and Ecomomics of Intervening in Historis Cities. Washingthon, D.C The Worls Bank.

Lubis, Hendra. 1990. Arahan Kebijaksanaan Pelestarian di Kawasan Jakarta Kota, Bandung: Tugas Akhir Jurusan Teknik Planologi ITB.
Peraturan Daerah Kotamadya Daerah Tingkat II Medan no. 6 Tahun 1988 tentang Pelestarian Bangunan dan Lingkungan yang Bernilai Sejarah Arsitektur Kepurbakalaan Sertan Penghijauan Daerah Kotamadya Daerah Tingkat II Medan.

Purbayu Budi Santosa dan Ashari, 2005. Analisis Statistik dengan Microsoft Excel dan SPSS, Yogyakarta. Andi Offset.

Rustam Hakim. 2006. Unsur Perancangan dalam Arsitektur Landsekap, Jakarta. Bumi Aksara.

Rypkema, Donovan. The Economics of Heritage Conservation, A paper Presented at "Capacity Building Training in Heritage Consevation". Bangka and Palembang 3- 9 July 2005.

Seminar Arsitektur angkatan IX. 1995. Deskripsi Warisan Arsitektural Kota Medan, Medan. Universitas Katholik ST. Thomas, SU.

Sinaga, Rumandap dkk. 1995. Deskripsi Warisan Arsitektural Kota Medan, Medan Seminar Arsitektur Angkatan XI Semester IX T.A 1994/1995.

Sinulingga, Budi D. 1999. Pembangunan Kota, Tinjauan Regional dan Lokal,. Jakarta. Sinar Harapan.

Sibarani, J.P Martin. 2002. "Pengendalian Kawasan Pelestarian Kota Lama di Kawasan Kesawan, Medan”. Bandung: Tesis Magister Rancang Kota ITB.

Tarigan, Robinson. 2005. Perencanaan Pembangunan Wilayah, Edisi Revisi. Medan. Bumi Aksara.

Todaro, M.P. 2000. Pembangunan Ekonomi di Dunia Ketiga, Edisi Ketujuh, Erlangga, Jakarta.

Yulianto Sumalyo. 1995. Arsitektur Kolonial Belanda Di Indonesia, Yogyakarta. Gadjah Mada University Press. 